\title{
Definition of a 1-Mb homozygous deletion at 9q32-q33 in a human bladder-cancer cell line
}

\begin{abstract}
We performed detailed molecular analyses of a suspected homozygous deletion on chromosome 9q32-q33 in a bladder-cancer cell line (KYBTDS) derived from a superficial papillary transitional cell carcinoma (TCC). We examined 13 sequence-tagged site (STS) markers mapped along 9q32-q33 by polymerase chain reaction (PCR), and used 13 bacterial artificial chromosome (BAC)/bacteriophage P1-derived artificial chromosome (PAC) genomic clone probes representing these STS markers as probes for dualcolor fluorescence in situ hybridization (FISH) analyses to define the deleted region cytogenetically and at the molecular level. Southern blotting confirmed the findings. This combination of techniques revealed that the homozygous deletion in the KYBTDS cell line involved less than 1 megabase of DNA, flanked by markers A003P42 and SGC33380. This interval overlaps part of a common region of deletion observed in a number of primary bladder cancers; moreover, the DNA sequence within the 1-Mb segment corresponds to part of a YAC genomic clone that encompasses a putative tumor suppressor gene, DBCCR1.
\end{abstract}

Key words Bladder cancer • Chromosome 9q32-33 . DBCCR1 · Homozygous deletion - KYBTDS · FISH · Southern blotting

H. Fujiwara $\cdot$ M. Emi $(\bowtie) \cdot$ H. Nagai $\cdot$ K. Ohgaki

Department of Molecular Biology, Institute of Gerontology,

Nippon Medical School, 1-396 Kosugi-cho, Nakahara-ku, Kawasaki 211-8533, Japan

Tel. +81-44-733-5230; Fax +81-44-733-5192

e-mail: memi@nms.ac.jp

H. Fujiwara $\cdot$ K. Ohgaki $\cdot$ M. Akimoto

Department of Urology, Nippon Medical School, Tokyo, Japan

I. Imoto

Medical Research Institute, Tokyo Medical and Dental University,

Tokyo, Japan

O. Ogawa

Department of Urology, Faculty of Medicine, Kyoto University,

Kyoto, Japan

T. Habuchi

Department of Urology, Faculty of Medicine, Akita University

School, Akita, Japan

\section{Introduction}

Carcinoma of the bladder is the most common cancer of the lower urinary tract. In bladder tumors, loss of heterozygosity $(\mathrm{LOH})$ has been described on several chromosomes, including chromsomes 8, 10, 11, 17, and 18 (Olumi et al. 1990; Knowles et al. 1993; Brewster et al. 1994; Devlin et al. 1994; Habuchi et al. 1995; Shaw and Knowles 1995; Takle and Knowles 1996; Kagan et al. 1998). However, chromosome 9 is the most frequent site of allelic loss in cancers of the bladder and urinary duct, which, together, are classified as transitional cell carcinomas (TCCs); this observation has been consistent worldwide (Olumi et al. 1990; Dalbagni et al. 1993; Habuchi et al. 1993; Knowles et al. 1994). In fact, $\mathrm{LOH}$ at loci on chromosome 9 has been detected in more than half of all bladder cancers examined, regardless of their grades and stages (Knowles et al. 1994; Ohgaki et al. 1999).

On the short arm of chromosome 9, the CDKN2A/p16 gene at 9 p21 is frequently deleted homozygously or has undergone intragenic mutations in bladder cancers (Williamson et al. 1995) This locus encodes a tumor suppressor that inhibits cyclin-dependent kinase $4(C D K 4)$ and $C D K 6$; inhibition of these cyclin-dependent kinases by the p16 protein causes cell-cycle arrest at G1. Loss of function of $C D K N 2 A / p 16$ is a critical tumorigenic event in many bladder cancers (Kamb et al. 1994; Nobori et al. 1994)

We previously performed deletion mapping in 85 urinarybladder cancers for allelic losses at 18 microsatellite loci along chromosome 9; we found two regions of common deletion, one at 9p21, flanked by D9S736 and D9S165, and the other at 9q31-q34, flanked by D9S58 and D9S61 (Ohgaki et al. 1999). We carried out a similar study specifically on the long arm of chromosome 9 in a different panel of TCC cancers, and detected commonly deleted regions at 9q13-31, 9q32-33, and 9q34 (Habuchi et al. 1995).

A putative tumor suppressor gene had been identified at 9q22.3 by Gorlin (1987) and by Hahn et al. (1996) through searches for the locus predisposing carriers of a dominant mutation to a neoplastic disease known as basal cell nevus 
syndrome (BCNS) or Gorlin syndrome. The gene involved turned out to be $\mathrm{PTCH}$, the human counterpart of Drosophila "patched", and it lies within one of the regions commonly deleted in human bladder cancers (McGarvey et al. 1998). However, to date, somatic mutations and rearrangements of $\mathrm{PTCH}$ have been found only in medulloblastomas and meningiomas, and not in bladder cancers (Xie et al. 1997).

Here, we describe a fine-scale molecular characterization of 9q32-q33 in a bladder-cancer cell line, KYBTDS, which we had suspected of harboring a homozygous deletion in that region (Nishiyama et al. 1999). By combining polymerase chain reaction (PCR), fluorescence in situ hybridization (FISH), and Southern-blotting experiments, we defined the critical region within a 1-Mb interval that contained two candidate expressed sequence tags (ESTs), of which one proved to be part of the DBCCR1 gene.

\section{Materials and methods}

\section{TCC cancer-cell line}

KYBTDS cells, derived from a grade 2 papillary pTa tumor (World Health Organization 1973; International Union Against Cancer 1978) were cultured in Dulbecco's modified Eagle's medium (DMEM, GIBCO-BRL Grand Island, NY, USA) medium supplemented with $10 \%$ fetal calf serum and antibiotics, at $37^{\circ} \mathrm{C}$, in a humidified incubator flushed with a mixture of $5 \% \mathrm{CO} 2 / 95 \%$ air.

\section{PCR analysis}

All PCRs were carried out using $10 \mathrm{ng}$ of template DNA with $2.25 \mathrm{mMMg}^{2+}, 250 \mathrm{nMdNTPs}, 333 \mathrm{nM}$ each forward and reverse primer, PCR buffer 2 (Perkin-Elmer, Foster City, CA, USA), and 0.6 units of Amplitaq Gold Polymerase (Perkin-Elmer, Foster City, CA, USA) in a total volume of $15 \mu \mathrm{l}$. The reactions were carried out in a model 9600 (Perkin-Elmer), using the following cycling protocol: initial denaturation at $94^{\circ} \mathrm{C}$ for $3 \mathrm{~min}$, then $94^{\circ} \mathrm{C}$ for $30 \mathrm{~s}$, $56^{\circ} \mathrm{C}-63^{\circ} \mathrm{C}$ for $30 \mathrm{~s}$, and $72^{\circ} \mathrm{C}$ for $30 \mathrm{~s}$, for 35 cycles, with a final extension at $72^{\circ} \mathrm{C}$ for $3 \mathrm{~min}$. The products were separated by electrophoresis in $2 \%$ agarose gels.

The nucleotide sequences for the forward and the reverse primers used for marker WI13592 were 5'TTGTTTTGTTTTGCTTCATTTTG-3' and 5'-GTGAAC CACGCCTTGGAC-3', and the nucleotide sequences for the forward and reverse primers for marker stSG46662 were 5'-GTTCTCAGCTGATCTTGGTGG-3' and 5'TGAATCAGCCTGGTCATCC.

\section{Southern blot analysis}

Genomic DNA from normal lymphoblasts and from the KYBTDS cell line was examined in parallel. Ten micro- grams of normal lymphoblast DNA and $10 \mu \mathrm{g}$ of the KYBTDS cell line DNA was digested overnight with restriction enzymes - EcoRI, HindIII, and BamHI - and then electrophoresed and transferred to a nylon membrane (Hybond- $\mathrm{N}^{+}$; Amersham, Uppsala, Sweden). The filter was hybridized at $65^{\circ} \mathrm{C}$ to probe WI13592 or probe A003P42 in hybridization buffer and washed stringently at $65^{\circ} \mathrm{C}$. Autoradiography was carried out overnight with an intensifying screen. Loading of equivalent amounts of DNA in each lane was confirmed by ethidium-bromide staining of the electrophoresed agarose gel, as well as by the hybridization results of an identical membrane with probes outside the deleted region, such as A003P42 and WI16257.

\section{BAC library screening}

Appropriate BAC clones were identified by the screening of DNA pools representing commercially available BAC libraries (Research Genetics, Huntsville, AL, USA), with STS markers mapped to the region under study, according to the distributor's recommendations. PCR experiments were performed as described above.

Fluorescence in situ hybridization (FISH)

To assign the location of the homozygous deletion at 9q3233 on metaphase chromosomes, BAC clones carrying human sequences containing each of the mapped STS markers served as the probes for FISH. Fluorescence in situ hybridization was carried out as described (Mukae et al. 1998). The cosmid DNAs were labeled with biotin-16deoxyuridine triphosphate (dUTP) by nick-translation and hybridized to denatured chromosomes, at a final concentration of $25 \mathrm{ng} / \mathrm{ml}$, in $50 \%$ formamide, $10 \%$ dextran sulfate, $2 \times$ standard saline citrate (SSC), $0.2 \mathrm{mg} / \mathrm{ml}$ Cot- 1 DNA (GIBCO/BRL, Rockville, MD, USA), $2 \mathrm{mg} / \mathrm{ml}$ salmon sperm DNA, and $2 \mathrm{mg} / \mathrm{ml}$ coli Escherichia tRNA. Hybridized signals were detected with fluorescein isothiocyanateavidin (Boehringer Mannheim, Mannheim, Germany). Metaphase cells were counterstained with 4', 6-diamidino2-phenylindole, and the slides were examined through a Nikon epifluorescent microscope (Nikon, Tokyo, Japan) equipped with a charge-coupled device (CCD) camera (Photometrics, Tucson, AZ, USA). Images were captured with Quips (Vysis, Tokyo, Japan) software and processed with Adobe Photoshop 4.0 software (San Jose, CA, USA).

\section{Results}

To define, at the molecular level, a suspected region of homozygous deletion in the cell line (KYBTDS) derived from a grade 2 papillary pTa TCC tumor (Nishiyama et al. 1999), we amplified 13 STS loci, mapped along 9q32-q33 (physical and genetic map information obtained from http://www.ncbi.nlm.nih.gov/genemap/map), by PCR, in genomic DNA from the cancer-cell line and from lympho- 
$\begin{array}{lllllr}\text { stSG31890 } & \text { WI15047 } & \text { WI13592 } & \text { SGC33380 } & \text { stSG4247 } & \text { stSG27194 }\end{array}$

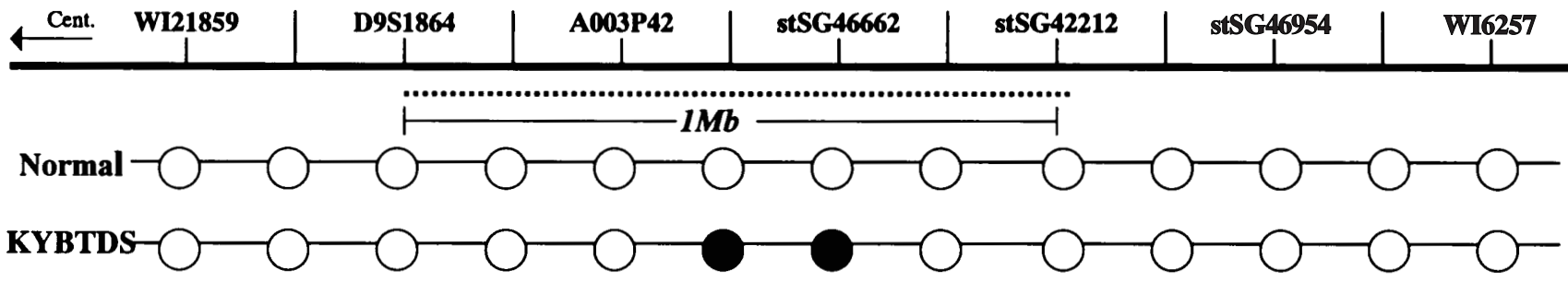

Normal KYBTDS

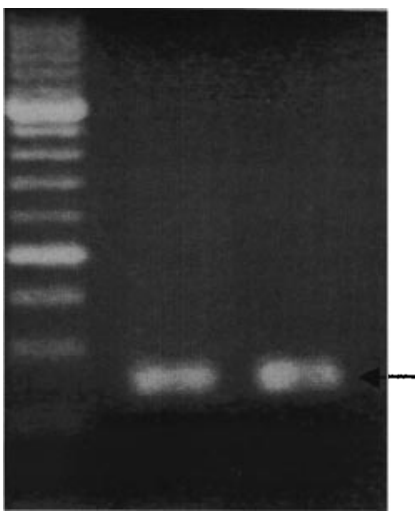

A003P42
Normal KYBTDS

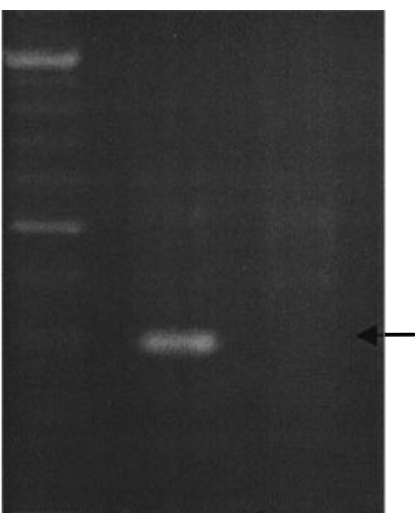

WI13592

Fig. 1. Fine genetic map of the critical region on 9q32-q33, and results of polymerase chain reaction (PCR) analysis. STS markers lying between D9S1864 and D9S258 along the 9q32-q33 region are shown at the top. The physical and genetic map was obtained from the National Center for Biotechnology Information (NCBI) database at http://

blasts. On the centromeric end of the deletion, the markers W121859, stSG31890, D9S1864, WI15047, and A003P42 were all amplified from the DNA of KYBTDS cells, suggesting that at least one allele of each sequence-tagged site was retained (Fig. 1).

When we tested markers WI13592 and stSG46662, however, no PCR product was amplified in the KYBTDS cell line, clearly showing that both alleles for those markers had been lost. Telomeric to WI13592 and stSG46662, markers SGC33380, stSG42212, stSG42475, stSG46954, stSG27194, and WI6257 were amplified from the genomic DNA of KYBTDS cells, so at least one allele of each of these markers was retained.

Genomic DNAs from normal lymphoblasts and from the KYBTDS cell line were examined further by Southern blotting, after separate digestions with EcoRI, HindIII, and BamHI, using WI13592 and stSG46662 as probes. Figure 2 displays an autoradiogram of a Southern blot probed with WI13592. Strong signals were detected on each lane containing normal lymphoblast DNA (lanes 1, 3, and 5), but no signal was detected on corresponding lanes containing KYBTDS DNA (lanes 2, 4, and 6). This procedure con-

firmed the homozygous deletion of the narrow region marked by WI3592 and stSG46662.

$\mathrm{BAC} / \mathrm{PAC}$ clones for FISH analysis were newly isolated by screening two-dimensionally pooled BAC or PACs by PCR with all 13 of the above STS markers distributed along the 9q32-q33 map. FISH analysis to detect loss of chromosomal material on $9 \mathrm{q}$ was carried out, using each of these 13 $\mathrm{BAC} / \mathrm{PAC}$ clones as a probe, on metaphase chromosomes prepared from normal lymphoblasts and from KYBTDS cells.

Figure 3 shows a representative result of dual-color FISH analysis, in which the BAC probe for WI13592 is displayed as a green signal and the BAC probe for D9S177 (outside the deleted region) yields a red signal. On metaphase chromosomes prepared from normal lymphoblasts, both green and red signals were clearly visible next to each other. On the other hand, when the same dual-color FISH was performed on metaphase chromosomes of the KYBTDS cell line, only red signals were detected, demonstrating that both alleles of genomic DNA represented by marker WI13592 were missing from the cancer cells. 


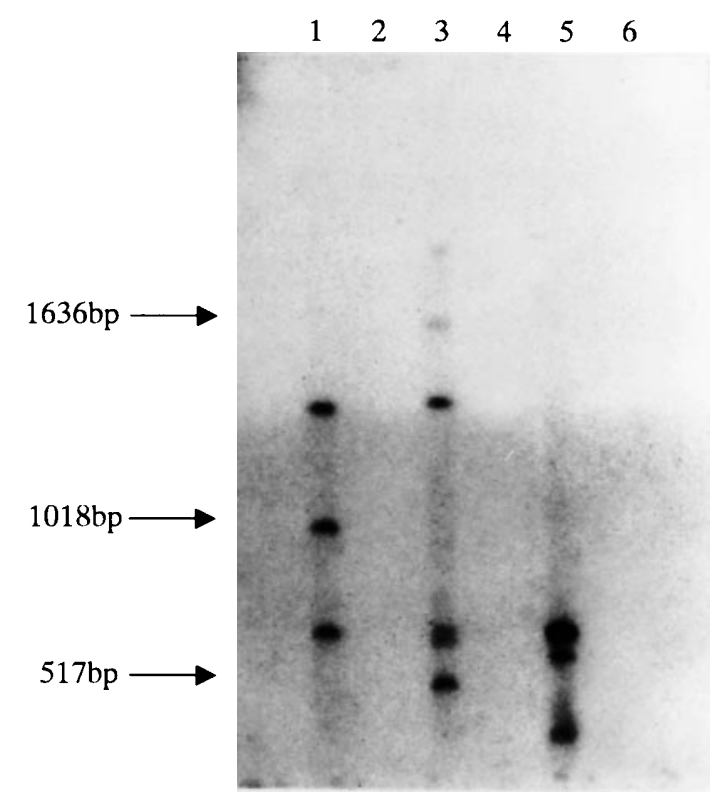

Fig. 2. Southern blot demonstrating homozygous deletion at marker WI13592. Genomic DNAs digested separately with EcoRI (lanes 1 and 2), HindIII (lanes 3 and 4), and Bam HI (lanes 5 and 6) were electrophoresed, then transferred to a nylon membrane and hybridized with a probe corresponding to WI13592. Lanes 1, 3, and 5 contain DNA derived from normal lymphoblasts; lanes 2, 4, and 6 contain DNAs from the bladder-cancer cell line KYBTDS. Loading of equivalent amounts of DNA in each lane was confirmed by ethidium-bromide staining of the electrophoresed agarose gel, as well as by hybridization results of an identical membrane with probes outside the deleted region, such as A003P42 and WI6257

However, FISH analysis using BAC probes representing WI121859, stSG31890, D9S1864, WI15047, and A003P42 on the centromeric side of the homozygous deletion gave positive fluorescent signals on both normal cells and KYBTDS cells. Similarly, BAC probes isolated for SGC33380, stSG42212, stSG42475, stSG46954, stSG27194, and WI6257 on the telomeric side of the homozygous deletion gave positive fluorescent signals on both normal cells and the KYBTDS cells.

These results demonstrated that the homozygous deletion on $9 \mathrm{q}$ in the KYBTDS cell line was confined to a $1-\mathrm{Mb}$ interval flanked by the marker A003P42, on the centromeric side, and the marker SGC33380, on the telomeric side, as shown in Fig. 1. The homozygously deleted region on 9q32-q33 revealed in this study overlapped with the commonly deleted region on $9 \mathrm{q} 32-\mathrm{q} 33$, encompassed by an $840-\mathrm{kb}$ YAC, that was previously detected by one of us in primary TCCs (Habuchi et al. 1997). Two of the STSs within the homozygously deleted region (WI13592 and stSG46662) were identified as transcribed sequences through analysis of the Genome Data Base, and we now consider them to represent candidate tumor suppressor genes. Unexpectedly, one of these sequences coincides with part of the DBCCRI gene (Habuchi et al. 1997) present within the 840-kb YAC described above.

\section{Discussion}

Loss of material on chromosome 9 has been the most common genetic alteration observed in transitional-cell carcinomas (TCCs) to date. The 9q32-q33 region, in particular, has been a focus of intense research to identify a tumor suppressor gene related to the development of bladder cancers, because evidence derived from independent deletion-mapping studies of $9 \mathrm{q}$ have revealed common deletions in that region. For instance, we undertook a high-resolution deletion-mapping effort involving 85 primary bladder cancers, using 18 microsatellite loci on chromosome 9 , and defined a commonly deleted region within 9q31-q34 in an interval flanked by D9S58 and D9S61 (Ohgaki et al. 1999). One of us (Habuchi et al. 1995) independently carried out deletion mapping in a different panel of primary bladder cancers, and defined a narrow, commonly deleted region at 9q32-q33 flanked by markers D9S1848 and AFMA239XA9.

In regard to homozygous deletions in TCCs, in addition to the frequent homozygous deletions of the CDKN2A/p16 locus on 9p21 (Cairns et al. 1995; Williamson et al. 1995), we discovered a homozygous deletion at 9q32-q33 in the bladder-cancer cell line, KYBTDS. At first, the deleted region was estimated by PCR analysis to be approximately $6 \mathrm{Mb}$ in extent, on the basis of the genetic map available at the time. By taking advantage of the high-density map constructed recently for the human genome, and by combining PCR, Southern blotting, and dual-color FISH experiments, we have now confined the homozygously deleted region in the KYBTDS TCC cell line to an interval of approximately $1 \mathrm{Mb}$. The $1-\mathrm{Mb}$ interval detected as a homozygous deletion in the KYBTDS cell line was also defined as a common region of deletion observed in the majority of primary bladder cancers. This combination of evidence supports the notion that the interval is a locus for a tumor suppressor gene involved in the genesis of bladder cancer. However, confirmation of a similar finding in regard to homozygous deletion in other TCC cell lines is necessary before a definite conclusion can be drawn.

Of the EST/cDNAs identified within this interval, one of the ESTs was not characterized, and no information was available as to function. However, one of these ESTs coincided with part of the DBCCR1 gene we had found in an earlier LOH study to be present on a 840-kb YAC that encompassed the commonly deleted region (Habuchi et al. 1997; 1998). However, as no somatic mutations have been observed in the DBCCR1 gene, it would appear that this gene is inactivated in bladder cancers by other mechanisms (e.g., allelic loss, methylation, or even haplo-insufficiency). In this connection, it is intriguing to recall the finding reported by Habuchi et al. (1998) that the expression of DBCCR1 mRNA in some bladder cancer cells was silenced by the hypermethylation of a $5^{\prime} \mathrm{CpG}$ island. Because several lines of evidence have drawn attention to this particular genomic region, investigations into the structures and functions of the two candidate genes, DBCCR1 (WI13592) and unknown gene (stSG46662) would help to 


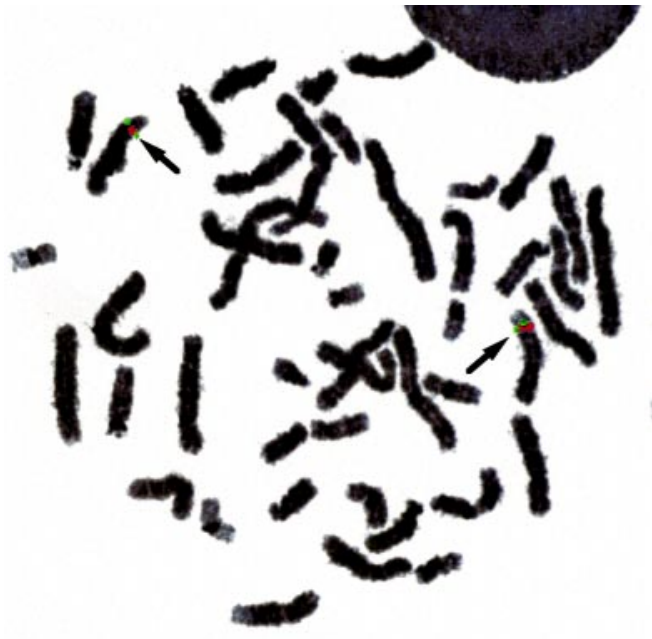

Normal

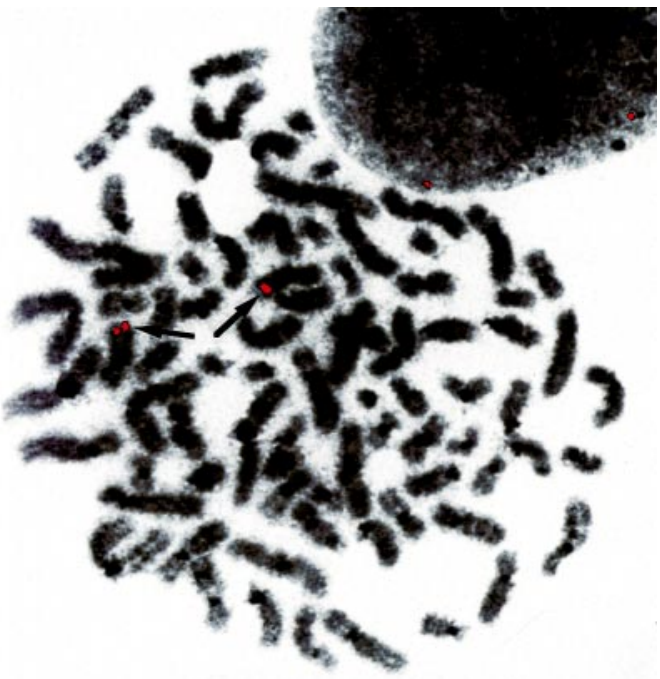

KYBTDS
Fig. 3. Dual-color fluorescence in situ hybridization (FISH) analysis demonstrating homozygous deletion around the WI13592 marker. Control ("normal") lymphoblasts were simultaneously hybridized with human BAC clone 319A21 (D9S177) and 13601 (WI13592) (BAC) clones representing D9S177 (red) and WI13592 (green); both signals

clarify the significance of the genetic alterations that are so frequently observed at 9q32-q33 in urinary-bladder cancers.

\section{References}

Brewster SF, Gingell JC, Browne S, Browne KW (1994) Loss of heterozygosity on chromosome $18 \mathrm{q}$ is associated with muscle-invasive transitional cell cancer of the bladder. Br J Cancer 70:697-700

Cairns P, Polascik TJ, Eby Y, Tokono K, Califano J, Merlo A, Mao L, Herath J, Jenkins R, Westra W, Rutter JL, Buckler A, Gabrielson E, Tockman M, Cho KR, Hendrick L, Bova GS, Isaacs W, Koch W, Schwab D, Sidransky D (1995) Frequency of homozygous deletion at p16/CDKN2A in primary human tumors. Nat Genet 11:210-212

Dalbagni G, Presti J, Reuter V, Fair WR, Cordon-Cardo C (1993) Genetic alterations in bladder cancer. Lancet 342:469-471

Devlin J, Keen AJ, Knowles MA (1994) Homozygous deletion mapping at 9p21 in bladder cancer defines a critical region within $2 \mathrm{cM}$ of IFNA. Oncogene 9:2757-2760

Gorlin RJ (1987) Nevoid basal-cell carcinoma syndrome. Medicine (Baltimore) 66:98-113

Habuchi T, Ogawa O, Kakehi Y, Ogura K, Koshiba M, Hamazaki S, Takahashi R, Sugiyama T, Yoshida O (1993) Accumulated allelic losses in the development of invasive urothelial cancer. Int J Cancer 53:579-584

Habuchi T, Devlin J, Elder PA, Knowles MA (1995) Detailed deletion mapping of chromosome $9 \mathrm{q}$ in bladder cancer: evidence for two tumour suppressor loci. Oncogene 11:1671-1674

Habuchi T, Yoshida O, Knowles MA (1997) A novel candidate tumour suppressor locus at $9 \mathrm{q} 32-33$ in bladder cancer: localization of the candidate region within a single 840-kb YAC. Hum Mol Genet 6:913-919

Habuchi T, Luscombe M, Elder PA, Knowles MA (1998) Structure and methylation-based silencing of a gene (DBCCR1) within a candidate bladder cancer tumor suppressor region at $9 \mathrm{q} 32-33$. Genomics 48:277-288 are visible next to each other on band q32-33 of chromosome 9. When hybridized with the same labeled probes, KYBTDS chromosomes displayed red signals, representing D9S177, but no green signal. Arrows indicate fluorescent point at $9 \mathrm{q} 32-33$

Hahn H, Wicking C, Zaphiropoulos PG, Gailani MR, Shanley S, Chidambaram A, Vorechovsky I, Holmberg E, Unden AB, Gillies S, Negus K, Smyth I, Pressman C, Leffell DJ, Gerrard B, Goldstein AM, Dean M, Toftgard R, Chenevix-Trench G, Wainwright B, Bale AE (1996) Mutations of the human homolog of Drosophila patched in the nevoid basal cell cancer syndrome. Cell 85:841-851

Kagan J, Liu J, Stein JD, Wagner SS, Babkowski R, Grossman BH, Katz RL (1998) Cluster of allelic losses within a $2.5 \mathrm{cM}$ region of chromosome 10 in high-grade invasive bladder cancer. Oncogene 16:909-913

Kamb A, Gruis NA, Weaver-Feldhaus J, Liu Q, Harshman K, Tavtigian SV, Stockert E, Day RS 3rd, Johnson BE, Skolnick MH (1994) A cell cycle regulator potentially involved in genesis of many tumor types. Science 264:436-440

Knowles MA, Elder PA, Williamson M, Cairns JP, Show ME, Law MG (1994) Allelotype of human bladder cancer. cancer Res 54:531-538

Knowles MA, Shaw ME, Proctor AJ (1993) Deletion mapping of chromosome 8 in cancers of the urinary bladder using restriction fragment length polymorphisms and microsatellite polymorphisms. Oncogene 8:1357-1364

McGarvey TW, Maruta Y, Tomaszewski JE, Linnenbach AJ, Malkowicz SB (1998) PTCH gene mutations in invasive transitional cell carcinoma of the bladder. Oncogene 17:1167-1172

Mukae N, Enari M, Sakahira H, Fukuda Y, Inazawa J, Toh H, Nagata S (1998) Molecular cloning and chracterization of human caspaseactivated DNase. Proc Natl Acad Sci USA 95:9123-9128

Nishiyama H, Takahashi T, Kakehi Y, Habuchi T, Knowles MA (1999) Homozygous deletion at the 9q32-33 candidate tumor suppressor locus in primary human bladder cancer. Genes Chromosom Cancer 26:171-175

Nobori T, Miura K, Wu DJ, Lois A, Takabayashi K, Carson DA (1994) Deletions of the cyclin-dependent kinase-4 inhibitor gene in multiple human cancers. Nature 368:753-756

Ohgaki K, Minobe K, Kurose K, Iida A, Habuchi T, Ogawa O, Kubota Y, Akimoto M, Emi M (1999) Two target regions of allelic loss on chromosome 9 in urinary-bladder cancer. Jpn J Cancer Res 90:957964

Olumi AF, Tsai YC, Nichols PW, Skinner DG, Cain DR, Bender LI, Jones, PA (1990) Allelic loss of chromosome 17p distinguishes high- 
grade from low-grade transitional cell cancers of the bladder. Cancer Res 50:7081-7083

Shaw ME, Knowles MA (1995) Deletion mapping of chromosome 11 in cancer of the bladder. Genes Chromosom Cancer 13:1-8

Takle LA, Knowles MA (1996) Deletion mapping implicates two tumor suppressor genes on chromosome $8 \mathrm{p}$ in the development of bladder cancer. Oncogene 12:1083-1087

Union Internationale Contre le Cancer (1978) TNM Classification of malignant tumors of the bladder, 3rd edn. UICC, Geneva, pp 113117
Williamson MP, Elder PA, Shaw ME, Devlin J, Knowles MA (1995) p16 (CDKN2) is a major deletion target at 9q21 in bladder cancer. Hum Mol Genet 4:1569-1577

World Health Organization (1973) Histological typing of urinary bladder tumors. In: Mostofi FK (ed) International histological classification of tumors, no. 10. Geneva, WHO

Xie J, Johnson RI, Zhang X, Bare JW, Waldman FM, Cogen PH, Menon AG, Warren RS, Chen LC, Scott MP, Epstein EH Jr (1997) Mutations of the PATCHED gene in several types of sporadic extracutaneous tumors. Cancer Res 57:2369-2372 